\title{
Reclassification of Non-alternating Locative Verbs in English
}

Wookyung Park ${ }^{\dagger}$

Kyungpook National University

\begin{abstract}
This study investigates non-alternating locative verbs in English, and reclassifies them on the basis of two English corpora-COCA and GloWbE-which were chosen because of their interface design, database design, and architecture. Considering that Pinker's classification was presented in 1989 but was based on the English used before 1989, the data from COCA (1990-2012) suits this research purpose better as it is being used to contrast. GloWbE was released in 2013 and contains data for 2012-2013. The corpus is a good platform to access authentic language sources currently in global use. The following questions are explored in this research: (1) Have the non-alternating locative verbs been used in previous classifications (Pinker, 1989; Levin, 1993)? (2) What type of verbs and how many verbs change their classes? (3) Is it possible to present a revised classification of locative verbs in English? This study showed that 10 verbs changed their classes, from the ground-only to the alternating verb class. Based on these results, a revised classification of non-alternating locative verbs was created.
\end{abstract}

Keywords: non-alternating locative verbs, reclassification, corpus, COCA, GloWbE

\section{Introduction}

Locative verbs are related to putting an entity in a location in some manner (Levin, 1993). Among locative verbs, non-alternating locative verbs are defined as the following by Pinker (1989): content-oriented verbs cannot merely specify the movement of a theme to a goal location but must specify some particular manner of causation or motion; likewise, container-oriented verbs must not merely specify a change of state in a final scene but must specify what that state is. Otherwise, these verbs would all be synonymous with other verbs such as put and fill or cover.

\footnotetext{
+ Corresponding author: gisg@hanmail.net
} 
Consider the following examples:

(1) Content-oriented non-alternating form
a. John poured water into the cup. $\rightarrow$ Figure-only verb
b. *John poured the cup with water.

(2) Container-oriented non-alternating form

a. John filled the cup with water. $\rightarrow$ Ground-only verb

b. *John filled water into the cup.

In (1), the water corresponding to Figure (content) of the sentence appears as the direct object of the verb, whereas the cup corresponding to the Ground (container) is not allowed in the direct object position. On the contrary, as shown in (2), when water corresponds to the Figure of the sentence, it is located in the direct object position, which sentence is unacceptable. That is, the verb pour is allowed to take only Figure argument as its direct object and the verb fill is allowed to take only Ground argument as its direct object. If the verb accepts only one form, either content-oriented form or container-oriented form, the verb is classified as a non-alternating locative verb.

However, a small number of verbs cannot work as they were intended to be used. The following sentence can be a counter-example that is not used as it is intended.

(3) Scott recalls challenging Greg to emblazon Gagwear's logo on his skin.1) The verb emblazon is classified as a non-alternating container verb in terms of semantic behavior. That is, this verb is used only as a Ground verb. The verb takes only a container entity as a direct object and only can be used in the

1) Source information: COCA

Date 2002

Publication information Vol. 24 Issue 11, p109, 26p, 1c

Title THE INC 500 List 2002.

Source Inc.

\footnotetext{
Expanded context:

Cannella \# 4\% of the Inc. 500 founders surveyed hired CEOs to replace themselves $13 \%$ of the Inc. 500 CEOs surveyed said they have been involved in patent litigation BRAND OF BROTHERS \# Take two ambitious guys (competitive brothers, no less), fuel them with a couple of cocktails, and unleash them on Los Angeles's Sunset Strip. What do you get? Tattoos. The year was 1996, and Scott and Greg Alterman of apparel company Gagwear (\#430) were at their first big trade show. "Slightly buzzed, "Scott recalls challenging Greg to emblazon Gagwear's logo on his skin. The deal: Scott would get the same tattoo, and he would even go first -- but if Greg chickened out, he would owe Scott $\$ 10,000$. Both followed through: Scott's tattoo is on his back, Greg's is on his leg. Today Greg suggests that the tattoos demonstrate fidelity -- to both brother and business.
} 
with construction. However, emblazon is used as a Figure verb, as shown in (3), and as a result, it can be used in a both constructions, the into/onto and with form.

Likewise, the discordance between existing classification assorted by Pinker in 1989 and authentic material observed by empirical researches is revealed. In order to address these limitations, every non-alternating locative verb will be investigated with two corpora. Through this process, a verb can be verified as to whether it has been used as it is intended by the previous classification. Accordingly, based on the data and analysis, a revised classification of non-alternating locative verbs will be presented.

\section{Previous Researches}

The locative alternation has received lots of attention, mostly about the mechanisms for classifying the locative verbs. There are two mainstream classifications which were done by the syntactic and semantic perspectives.

\subsection{Syntactic Classification of Non-alternating Locative Verbs}

Locative verbs are part of the category of verbs of putting (Croft, 1991; Dixon, 1991; Gruber, 1976; Jackendoff, 1985; Levin and Rappaport, 1988). Levin (1993) proposed an analysis of English verbs according to multiple types of alternations. Each verb can be described by the set of alternations it undergoes. In her preliminary observation, there is enough correlation between semantic factors and syntactic behaviors to form verb classes. She has defined about 200 verb classes, where, in each class, verbs share similar semantics and a certain number of alternations 2 ).

2) Alternations

(i) Causative Alternation

a. Tamara poured water onto the plants.

b. Water poured onto the plants.

(ii) Middle Alternation

a. Tamara poured water onto the plants.

b. *Water pours easily onto the plants.

(iii) Conative Alternation

a. Tamara poured water into the bowl.

b. *Tamara poured at water into the bowl. 
Among more than 200 verb classes above, 5 verb classes correspond to locative verbs that are targeted in this study. Each verb class can be described and characterized by the allowance of alternations. The total number of locative verbs is around 160 and the class names are as following: Pour Verbs, Coil Verbs, Funnel Verbs, Spray/Load Verbs and Fill Verbs. Those verbs refer to putting an entity in some location in some manner. Among those of five types of verb classes, four classes correspond to the non-alternating locative verbs 3 ).

Table 1. Non-alternating verb class (Levin, 1993)

\begin{tabular}{c|l}
\hline \multirow{3}{*}{$\begin{array}{c}\text { Pour Verbs } \\
+\end{array}$} & $\begin{array}{l}\text { Dribble, drip, pour, slop, slosh, spew, spill, spurt, coil, curl, loop, roll, } \\
\text { Coil Verbs } \\
+\end{array}$ \\
spin, twirl, twist, whirl, wind, bang, channel, dip, dump, funnel, \\
hammer, ladle, pound, push, rake, ram, scoop, scrape, shake, shovel, \\
siphon, spoon, squeeze, squish, squash, sweep, tuck, wad, wedge, \\
wipe, wring
\end{tabular}

(iv) Coreferential interpretation of pronouns

a. Tamara poured the water over her.

(v) Zero-related Nominal

a. a spill

3) Verb classes and Alternations (Levin, 1993)

\begin{tabular}{cccccc}
\hline & Pour Verbs & Coil Verbs & Funnel Verbs & $\begin{array}{c}\text { Spray/Load } \\
\text { Verbs }\end{array}$ & Fill Verbs \\
\hline \hline Locative Alternation & $*$ & $*$ & $*$ & 0 & $*$ \\
\hline Causative Alternation & 0 & 0 & $*$ & $0 / *$ & $*$ \\
\hline Middle Alternation & $*$ & 0 & $*$ & - & - \\
\hline Conative Alternation & $*$ & $*$ & $*$ & $\begin{array}{c}\text { o } \\
\text { (some verbs) }\end{array}$ & - \\
\hline $\begin{array}{c}\text { Coreferential Interpretation } \\
\text { of Pronouns }\end{array}$ & $\mathrm{o}$ & $\mathrm{o}$ & - & $\begin{array}{c}\mathrm{o} \\
\text { (some verbs) }\end{array}$ & - \\
\hline Zero-related Nominal & $\begin{array}{c}\text { o } \\
\text { (few verbs) }\end{array}$ & $\mathrm{o}$ & $\begin{array}{c}\mathrm{o} \\
\text { (some verbs) }\end{array}$ & $\begin{array}{c}\mathrm{o} \\
\text { (some verbs) }\end{array}$ & - \\
\hline
\end{tabular}


The members of the set of Pour Verbs cannot undergo a locative alternation. Based on the research of Anderson (1971, 1977), Carter (1988), Dixon (1989) Larson (1990), Jeffries and Willis (1984), Levin (1993) classified a total of seven words as the member of this class: dribble, drop, pour, slosh, spew, spill, spurt. All of these verbs relate to putting entity - usually liquids - on surfaces or in containers.

Coil Verbs have the same syntactic patterns as the Pour Verbs in a locative alternation. they don't need to be separated from the perspective of locative alternation, even in this study. Only the semantic feature is different between the two types in this research scope. Contrary to the entity of Pour Verbs construction, the one in Coil Verbs construction is not liquids but strings and usually used with the preposition around because of its meaning. This class contains nine verbs in Levin's research (1993): coil, curl, loop, roll, spin, twirl, twist, whirl, wind.

Funnel Verbs usually involve putting entities in spatially confined locations. These verbs show a preference for into rather than in and for onto rather than on. 26 verbs are included in this class: bang, channel, dip, dump, funnel, hammer, ladle, pound, push, rake, ram, scoop, scrape, shake, shovel, siphon, spoon, squeeze, squish, squash, sweep, tuck, wad, wedge, wipe, wring.

Fill Verbs are only found in the with construction and these verbs cannot undergo locative alternation. A few verbs in this type allow alternation with and in. When a sentence includes all of elements, one figure argument, one ground argument, one preposition and a proper verb, it can be considered within the this research scope. Besides Gawron (1983, 1986), Hall (1965), Jolly (1987), they (Levin \& Rappaport, 1988; Rappaport \& Levin, 1992) created a list of this type of content. The number of the verbs in this class is 95 .

\subsection{Semantic Classification of Non-alternating Locative Verbs}

The locative verbs are classified according to the semantic features, which is based on the lexical rules. Pinker (1989: 49) claimed that the locative verbs denote a transfer of substance or set of objects (the theme, content of locatum) into or onto a container or surface (the goal, container, or location). The locative constructions taking the preposition into or onto are labeled content-oriented or theme-object forms, and those taking the preposition with, named container-oriented or goal-object forms, respectively.

142 locative verbs were compiled according to the semantic cohesiveness and they formed fourteen subclasses. The targeted 142 verbs in the Pinker's research were put 
together with the verbs that were collected by Rappaport and Levin (1985) and those that he heard and read for several years while working on his research (Pinker, 1989).

109 non-alternating locative verbs are also divided into two categories. They are 33 content-oriented verbs and 76 container-oriented verbs, respectively.

Table 2. Non-alternating locative verbs by Pinker (1989)

\begin{tabular}{|c|c|c|}
\hline \multicolumn{3}{|c|}{ Content-oriented or into/onto verbs (Non-alternating) } \\
\hline Name of Class & Features & $\operatorname{Verbs}(\mathrm{N}=33)$ \\
\hline $\begin{array}{l}\text { Non-alternating. } 1 \\
\qquad(\mathrm{~N}=10)\end{array}$ & $\begin{array}{l}\text { A mass is enabled to move } \\
\text { via the force of gravity. }\end{array}$ & $\begin{array}{l}\text { Dribble, drip, drizzle, dump, ladle, } \\
\text { pour, shake, slop, slosh, spill, }\end{array}$ \\
\hline $\begin{array}{l}\text { Non-alternating. } 2 \\
\quad(\mathrm{~N}=6)\end{array}$ & $\begin{array}{l}\text { Flexible object extended in } \\
\text { one dimension is put around } \\
\text { another object. }\end{array}$ & Coil, spin, twirl, twist, whirl, wind \\
\hline $\begin{array}{l}\text { Non-alternating. } 3 \\
\quad(\mathrm{~N}=8)\end{array}$ & $\begin{array}{l}\text { Mass is expelled from inside } \\
\text { an entity. }\end{array}$ & $\begin{array}{l}\text { Emit, excrete, expectorate, expel, } \\
\text { exude, secrete, spew, vomit }\end{array}$ \\
\hline $\begin{array}{l}\text { Non-alternating. } 4 \\
\quad(\mathrm{~N}=9)\end{array}$ & Verbs of attachment & $\begin{array}{l}\text { Attach, fasten, glue, nail, paste, pin, } \\
\text { staple, stick, tape }\end{array}$ \\
\hline \multicolumn{3}{|c|}{ Container-oriented or with verbs (Non-alternating) } \\
\hline Name of Class & Features & Verbs $(\mathrm{N}=76)$ \\
\hline $\begin{array}{l}\text { Non-alternating. } 5 \\
\quad(\mathrm{~N}=19)\end{array}$ & $\begin{array}{l}\text { A layer completely covers of } \\
\text { surface. }\end{array}$ & $\begin{array}{l}\text { Fill, cover, pave, occupy, bandage, } \\
\text { face, flood, deluge, douse, inundate, } \\
\text { blanket, coat, encrust, inlay, pad, } \\
\text { plate, shroud, smother, tile, line, } \\
\text { edge }\end{array}$ \\
\hline $\begin{array}{l}\text { Non-alternating. } 6 \\
\quad(\mathrm{~N}=22)\end{array}$ & $\begin{array}{l}\text { Addition of object an abject } \\
\text { or mass to a location causes } \\
\text { an aesthetic or qualitative, } \\
\text { often evaluative, change in } \\
\text { the location }\end{array}$ & $\begin{array}{l}\text { Pollute, adorn, burden, infect, season, } \\
\text { endow, trim, clutter, deck, dirty, } \\
\text { embellish, emblazon, enrich, festoon, } \\
\text { garnish, imbue, litter, ornament, } \\
\text { replenish, soil, stain, taint }\end{array}$ \\
\hline $\begin{array}{l}\text { Non-alternating. } 7 \\
\quad(\mathrm{~N}=15)\end{array}$ & $\begin{array}{l}\text { A mass is caused to be } \\
\text { coextensive with a solid or } \\
\text { layer-like medium }\end{array}$ & $\begin{array}{l}\text { Drench, interlace, soak, infuse, } \\
\text { interlard, interleave, intersperse, } \\
\text { interweave, lard, ripple, vein, } \\
\text { impregnate, saturate, stain, suffuse }\end{array}$ \\
\hline $\begin{array}{l}\text { Non-alternating. } 8 \\
\quad(\mathrm{~N}=12)\end{array}$ & $\begin{array}{l}\text { An object or mass impedes } \\
\text { the free movement of, from, } \\
\text { or through the object in } \\
\text { which it is put }\end{array}$ & $\begin{array}{l}\text { Block, plug, lash, choke, clog, dam, } \\
\text { stop up, bind, chain, entangle, } \\
\text { lasso, rope }\end{array}$ \\
\hline $\begin{array}{l}\text { Non-alternating. } 9 \\
\quad(\mathrm{~N}=8)\end{array}$ & $\begin{array}{l}\text { A set of objects is } \\
\text { distributed over a surface }\end{array}$ & $\begin{array}{l}\text { Bombard, blot, dapple, riddle, } \\
\text { speckle, splotch, spot, stud }\end{array}$ \\
\hline
\end{tabular}




\subsection{Comparison between Two Previous Classifications}

In this section, the classifications that were previously classified, in terms of the syntactic and semantic perspective, are compared. Syntactic classification was researched by Levin in 1993 and semantic classification was done by Pinker in 1989. Each class of verbs are included in Table 3 for the comparison.

Table 3. Levin's \& Pinker's classification of non-alternating locative verbs

\begin{tabular}{|c|c|c|}
\hline & Levin's classification & Pinker's classification \\
\hline $\begin{array}{c}\text { Figure- } \\
\text { only } \\
\text { verbs }\end{array}$ & $\begin{array}{l}\text { Dribble, drip, pour, slop, slosh, spew, spill, } \\
\text { spurt, coil, curl, loop, roll, spin, twirl, twist, } \\
\text { whirl, wind, bang, channel, dip, dump, } \\
\text { funnel, hammer, ladle, pound, push, rake, } \\
\text { ram, scoop, scrape, shake, shovel, siphon, } \\
\text { spoon, squeeze, squish, squash, sweep, } \\
\text { tuck, wad, wedge, wipe, wring (n }=43 \text { ) }\end{array}$ & $\begin{array}{l}\text { Dribble, drip, drizzle, dump, ladle, } \\
\text { pour, shake, slop, slosh, spill, coil, } \\
\text { spin, twirl, twist, whirl, wind, emit, } \\
\text { excrete, expectorate, expel, exude, } \\
\text { secrete, spew, vomit, attach, fasten, } \\
\text { glue, nail, paste, pin, staple, stick, } \\
\text { tape }(\mathrm{n}=33)\end{array}$ \\
\hline $\begin{array}{c}\text { Ground- } \\
\text { only } \\
\text { verbs }\end{array}$ & $\begin{array}{l}\text { Adorn, anoint, bandage, bathe, bestrew, } \\
\text { bind, blanket, block, blot, bombard, carpet, } \\
\text { choke, cloak, clog, clutter, coat, contaminate, } \\
\text { cover, dam, dapple, deck, decorate, deluge, } \\
\text { dirty, douse, dot, drench, edge, embellish, } \\
\text { emblaze, encircle, encrust, endow, enrich, } \\
\text { entangle, face, festoon, fill, fleck, flood, } \\
\text { frame, garland, garnish, imbue, impregnate, } \\
\text { infect, inlay, interlace, interlard, interleave, } \\
\text { intersperse, interweave, inundate, lard, lash, } \\
\text { line, litter, mask, mottle, ornament, pad, } \\
\text { pave, plate, plug, pollute, replenish, repopulate, } \\
\text { riddle, ring, ripple, robe, saturate, season, } \\
\text { shroud, smother, soak, soil, speckle, splotch, } \\
\text { spot, staff, stain, stipple, stop up, stud, } \\
\text { suffuse, surround, swaddle, swathe, taint, } \\
\text { tile, trim, veil, vein, wreathe (n = 95) }\end{array}$ & $\begin{array}{l}\text { Fill, cover, pave, occupy, bandage, } \\
\text { face, flood, deluge, douse, inundate, } \\
\text { blanket, coat, encrust, inlay, pad, } \\
\text { plate, shroud, smother, tile, line, edge, } \\
\text { pollute, adorn, burden, infect, season, } \\
\text { endow, trim, clutter, deck, dirty, } \\
\text { embellish, emblazon, enrich, festoon, } \\
\text { garnish, imbue, litter, omament, } \\
\text { replenish, soil, stain, taint, drench, } \\
\text { interlace, soak, infuse, interlard, } \\
\text { interleave, intersperse, interweave, } \\
\text { lard, ripple, vein, impregnate, saturate, } \\
\text { suffuse, block, plug, lash, choke, } \\
\text { clog, dam, stop up, bind, chain, } \\
\text { entangle, lasso, rope, bombard, blot, } \\
\text { dapple, riddle, speckle, splotch, spot, } \\
\text { stud (n = 77) }\end{array}$ \\
\hline
\end{tabular}

In Figure-only verbs, the results of the two research are not consistent. Different reasons may be raised about this inconsistency. Even wad is classified as a Figure only verb in Levin's classification, but it is classified as an alternating verb in Pinker's classification. Drizzle and stick are Figure-only verbs in Pinker's classification, but they are alternating verbs in Levin's classification. Those kinds of verbs have shade backgrounds4). It might be just misclassified or they had a little different research scope and limit because of different viewpoints of the locative verbs. Therefore, in 
this study the overlapping verbs are included in the research scope. 15 verbs are overlapping between Levin's and Pinker's classification, which are expressed in bold type.

In Ground-only verbs, one verb falls into a different classification. According to Levin, Bestrew is classified as a Ground-only verb, which has shade background, but it is an alternating verb in Pinker's classification. 70 verbs are overlapping between two classifications. They are target verbs in this research and presented in bold type.

\section{Methodology}

\subsection{Data Collection}

In order to verify how locative verbs are used among English speakers, the following corpus engines are used: The Corpus of Contemporary American English (http:// corpus.byu.edu/coca/) (hereafter, COCA) ${ }^{5}$ ) which contains more than 450 million words of full-text data; The Corpus of Global Web-Based English (http://corpus. byu.edu/glowbe/) (hereafter, GloWbE) which is composed of 1.9 billion words from 1.8 million web pages in 20 different English-speaking countries.

Due to the design of each corpus, they are the most suitable corpora to investigate ongoing changes in the language. Especially, considering Pinker's classification was presented in 1989 and it was based on the English before 1989, the data from COCA (1990-2012) fits in well with this research purpose. In addition, GloWbE was released in 2013 and contains the data in 2012-2013. It provides a good opportunity to research authentic language sources currently in global use.

\subsection{Analysis Procedures}

This study is carried out by 5 steps listed below:

Step 1: Examining Sense and Usage of Verb that are included in both

Step 2: Observing the Corpus Data

\section{Step 3: Computing Figure Precedence Rate}

In this step, the results which are collected in step 2 are calculated to present the proportion of how much the Figure arguments take possessions of precedence over

4) Those verbs will be researched in-depth in the study of alternating locative verbs.

5) The data is regularly updated. It contains more than 520 million words of text at the present moment. 
the Ground argument. This numerical figure is a kind of relative frequency in statistics. The formula for FPR is below

$\mathrm{FPR}=\frac{\text { the number of Figure precedence }}{\text { the number of Figure precedence }+ \text { the number of Ground precedence }}$

Step 4: Calculating the confidence interval of the proportion

This research uses the standard error to calculate the confidence interval, which is a range of values likely to include the population mean.

All the locative verbs have different frequencies in sentence use. Therefore, one standard error cannot be applied to all the verbs. Each verb was calculated according to the mathematical formula individually.

A 95\% confidence interval for the FPR was calculated.6)

$$
\hat{p} \pm Z_{\alpha / 2} \sqrt{\frac{\hat{p}(1-\hat{p})}{n}}=\hat{p} \pm 1.96 \sqrt{\frac{\hat{p}(1-\hat{p})}{n}}
$$

For example, the FPR of the verb Flood in Type 2 indicates 0.182 in COCA, and the number of Figure precedence is 314 and that of Ground preceded sentences is 1409. That is, the total number of sentences used in COCA is 1723.7)

$0.182 \pm 1.96=\sqrt{\frac{0.182 \times 0.818}{1723}}=0.1638,0.2002$

Therefore, the confidence interval of flood is $0.1638 \sim 0.2002$.

6) $\hat{p}$ : Estimates were calculated from the samples of FPR.

$\mathrm{Z}_{0.025}=1.96$ (confidence level $\left.(1-\alpha)=0.95\right)$ )

7) Standard Error: $\sqrt{\frac{\hat{p}(1-\hat{p})}{n}}=\sqrt{\frac{0.182 \times 0.818}{1723}}=0.009295$

Margin of Error: $\pm Z_{\alpha_{/ 2}} \sqrt{\frac{\hat{p}(1-\hat{p})}{n}}= \pm 1.96 \times 0.009295= \pm 0.0182$

Lower limit: $\hat{p}-Z_{\alpha_{/ 2}} \sqrt{\frac{\hat{p}(1-\hat{p})}{n}}=0.182-0.0182=0.1638$

Upper limit: $\hat{p}+Z_{\alpha / 2} \sqrt{\frac{\hat{p}(1-\hat{p})}{n}}=0.182+0.0182=0.2002$ 
Step 5: Reclassifying the verbs

Based on a numerical value resulting from step 3 and 4 , all of the verbs are analyzed and reclassified if necessary.

The FPR of flood is 0.182 , which falls into the confidence interval. That is, the FPR is significant and the verb should be moved to alternating locative verb class.

\section{Results}

\subsection{Type 1: Figure-only Verbs}

There are four classes in the content-oriented non-alternating locative verbs by Pinker (1989) and there are 33. Levin presents 43 verbs in this class. There are 15 target verbs in this study which are overlapping between the two classifications. Any sentence is counted as long as the verb is used as a locative verb and the two arguments can be assigned as Figure and Ground respectively. The verbs of this type tend to be used with the prepositions on, over, from, around besides into and onto. All the verbs have been used as they were intended as seen in the following Table 4 .

Table 4. Observation of Figure-only verbs in COCA and GloWbE

\begin{tabular}{|c|c|c|c|c|c|c|}
\hline \multirow{2}{*}{ Verbs } & \multicolumn{3}{|c|}{ COCA } & \multicolumn{3}{|c|}{ GloWbE } \\
\hline & $\mathrm{F}$ prep $\mathrm{G}$ & G prep $F$ & FPR & $\mathrm{F}$ prep $\mathrm{G}$ & $G$ prep $F$ & FPR \\
\hline Dribble & 197 & 0 & 1.000 & 372 & 0 & 1.000 \\
\hline Drip & 943 & 0 & 1.000 & 1,044 & 0 & 1.000 \\
\hline Dump & 2,289 & 0 & 1.000 & 5,692 & 0 & 1.000 \\
\hline Ladle & 424 & 0 & 1.000 & 166 & 0 & 1.000 \\
\hline Pour & 9,042 & 0 & 1.000 & 18,597 & 0 & 1.000 \\
\hline Shake & 330 & 0 & 1.000 & 440 & 0 & 1.000 \\
\hline Slop & 85 & 0 & 1.000 & 120 & 0 & 1.000 \\
\hline Slosh & 136 & 0 & 1.000 & 90 & 0 & 1.000 \\
\hline Spill & 2,965 & 0 & 1.000 & 5,883 & 0 & 1.000 \\
\hline Coil & 80 & 0 & 1.000 & 93 & 0 & 1.000 \\
\hline Spin & 232 & 0 & 1.000 & 402 & 0 & 1.000 \\
\hline Twirl & 83 & 0 & 1.000 & 64 & 0 & 1.000 \\
\hline Twist & 172 & 0 & 1.000 & 238 & 0 & 1.000 \\
\hline Whirl & 107 & 0 & 1.000 & 90 & 0 & 1.000 \\
\hline Wind & 394 & 0 & 1.000 & 506 & 0 & 1.000 \\
\hline
\end{tabular}


Five classes are included in this type by Pinker's research and the number is 77. According to Levin, 95 verbs are classified into this category. The number of overlapping verbs between the two classifications is 70 and they are target verbs in this study. All of the sentences are counted as long as the verb is used as a locative verb and the two arguments can be assigned as Figure and Ground respectively. Most of verbs are used with with, but some verbs are used with the preposition in.

Table 5. Observation of Ground-only verbs in COCA and GloWbE

\begin{tabular}{|c|c|c|c|c|c|c|}
\hline \multirow{2}{*}{ Verbs } & \multicolumn{3}{|c|}{ COCA } & \multicolumn{3}{|c|}{ GloWbE } \\
\hline & F prep $G$ & $\mathrm{G}$ prep $\mathrm{F}$ & FPR & F prep $G$ & $G$ prep $F$ & FPR \\
\hline Deluge & 0 & 193 & 0.000 & 0 & 312 & 0.000 \\
\hline Douse & 0 & 556 & 0.000 & 0 & 1,082 & 0.000 \\
\hline Flood & 314 & 1,409 & 0.182 & 789 & 5,254 & 0.131 \\
\hline Inundate & 0 & 489 & 0.000 & 0 & 489 & 0.000 \\
\hline Bandage & 0 & 37 & 0.000 & 0 & 63 & 0.000 \\
\hline Blanket & 0 & 308 & 0.000 & 0 & 440 & 0.000 \\
\hline Coat & 0 & 2514 & 0.000 & 0 & 3,638 & 0.000 \\
\hline Cover & 0 & 22,017 & 0.000 & 0 & 63,019 & 0.000 \\
\hline Encrust & 0 & 215 & 0.000 & 0 & 303 & 0.000 \\
\hline Face & - & - & - & - & - & - \\
\hline Inlay & 4 & 3 & 0.571 & 28 & 8 & 0.778 \\
\hline Pad & 0 & 107 & 0.000 & 0 & 440 & 0.000 \\
\hline Pave & 0 & 406 & 0.000 & 0 & 68 & 0.000 \\
\hline Plate & 0 & 46 & 0.000 & 0 & 230 & 0.000 \\
\hline Shroud & 0 & 54 & 0.000 & 0 & 190 & 0.000 \\
\hline Smother & 0 & 231 & 0.000 & 0 & 491 & 0.000 \\
\hline Tile & 0 & 32 & 0.000 & 0 & 107 & 0.000 \\
\hline Line & 0 & 3,824 & 0.000 & 0 & 7,857 & 0.000 \\
\hline Edge & 0 & 282 & 0.000 & 0 & 286 & 0.000 \\
\hline Fill & 188 & 29,118 & 0.006 & 479 & 82,625 & 0.006 \\
\hline Adorn & 0 & 1,120 & 0.000 & 0 & 3,350 & 0.000 \\
\hline
\end{tabular}


Table 5. Continued 1

\begin{tabular}{|c|c|c|c|c|c|c|}
\hline \multirow{2}{*}{ Verbs } & \multicolumn{3}{|c|}{ COCA } & \multicolumn{3}{|c|}{ GloWbE } \\
\hline & F prep $G$ & G prep $F$ & FPR & F prep $G$ & $G$ prep $F$ & FPR \\
\hline Clutter & 0 & 447 & 0.000 & 0 & 773 & 0.000 \\
\hline Deck & 0 & 176 & 0.000 & 0 & 548 & 0.000 \\
\hline Dirty & 0 & 55 & 0.000 & 0 & 204 & 0.000 \\
\hline Embellish & 0 & 372 & 0.000 & 0 & 914 & 0.000 \\
\hline Endow & 0 & 1,092 & 0.000 & 0 & 5,543 & 0.000 \\
\hline Enrich & 0 & 336 & 0.000 & 0 & 1,648 & 0.000 \\
\hline Festoon & 0 & 419 & 0.000 & 0 & 457 & 0.000 \\
\hline Garnish & 0 & 1,655 & 0.000 & 0 & 1,065 & 0.000 \\
\hline Imbue & 46 & 899 & 0.049 & 253 & 2,763 & 0.084 \\
\hline Infect & 0 & 1,754 & 0.000 & 0 & 6,065 & 0.000 \\
\hline Litter & 0 & 1,276 & 0.000 & 0 & 3,633 & 0.000 \\
\hline Ornament & 0 & 115 & 0.000 & 0 & 319 & 0.000 \\
\hline Pollute & 0 & 159 & 0.000 & 0 & 874 & 0.000 \\
\hline Replenish & 53 & 83 & 0.390 & 239 & 345 & 0.409 \\
\hline Season & 0 & 117 & 0.000 & 0 & 324 & 0.000 \\
\hline Soil & 0 & 95 & 0.000 & 0 & 237 & 0.000 \\
\hline Stain & 0 & 659 & 0.000 & 0 & 1,142 & 0.000 \\
\hline Taint & 0 & 222 & 0.000 & 0 & 964 & 0.000 \\
\hline Trim & 0 & 465 & 0.000 & 0 & 578 & 0.000 \\
\hline Interlace & 0 & 54 & 0.000 & 0 & 173 & 0.000 \\
\hline Interlard & 0 & 3 & 0.000 & 0 & 6 & 0.000 \\
\hline Interleave & 0 & 15 & 0.000 & 0 & 49 & 0.000 \\
\hline Intersperse & 16 & 599 & 0.026 & 8 & 2,284 & 0.003 \\
\hline Interweave & 97 & 194 & 0.333 & 274 & 774 & 0.261 \\
\hline Lard & 0 & 67 & 0.000 & 0 & 112 & 0.000 \\
\hline Ripple & 22 & 116 & 0.159 & 46 & 59 & 0.438 \\
\hline Vein & 0 & 55 & 0.000 & 0 & 18 & 0.000 \\
\hline Drench & 0 & 186 & 0.000 & 0 & 386 & 0.000 \\
\hline Impregnate & 0 & 138 & 0.000 & 0 & 374 & 0.000 \\
\hline
\end{tabular}


Table 5. Continued 2

\begin{tabular}{|c|c|c|c|c|c|c|}
\hline \multirow{2}{*}{ Verbs } & \multicolumn{3}{|c|}{ COCA } & \multicolumn{3}{|c|}{ GloWbE } \\
\hline & $\mathrm{F}$ prep $\mathrm{G}$ & G prep $F$ & FPR & $\mathrm{F}$ prep $\mathrm{G}$ & $G$ prep $F$ & FPR \\
\hline Saturate & 0 & 569 & 0.000 & 0 & 1,744 & 0.000 \\
\hline Soak & 287 & 451 & 0.389 & 475 & 852 & 0.358 \\
\hline Stain & 0 & 659 & 0.000 & 0 & 1,142 & 0.000 \\
\hline Suffuse & 0 & 325 & 0.000 & 0 & 559 & 0.000 \\
\hline Block & 0 & 443 & 0.000 & 0 & 1,505 & 0.000 \\
\hline Chock & 0 & 500 & 0.000 & 0 & 806 & 0.000 \\
\hline Clog & 0 & 378 & 0.000 & 0 & 900 & 0.000 \\
\hline Dam & 0 & 11 & 0.000 & 0 & 50 & 0.000 \\
\hline Plug & 1,572 & 192 & 0.891 & 5,865 & 252 & 0.959 \\
\hline Stop Up & 0 & 3 & 0.000 & 0 & 5 & 0.000 \\
\hline Bind & 0 & 1,035 & 0.000 & 0 & 4,087 & 0.000 \\
\hline Entangle & 0 & 163 & 0.000 & 0 & 603 & 0.000 \\
\hline Lash & 0 & 245 & 0.000 & 0 & 482 & 0.000 \\
\hline Bombard & 0 & 574 & 0.000 & 0 & 3,228 & 0.000 \\
\hline Blot & 0 & 154 & 0.000 & 0 & 180 & 0.000 \\
\hline Dapple & 0 & 58 & 0.000 & 0 & 39 & 0.000 \\
\hline Riddle & 0 & 791 & 0.000 & 0 & 3,175 & 0.000 \\
\hline Speckle & 0 & 12 & 0.000 & 0 & 8 & 0.000 \\
\hline Splotch & 0 & 43 & 0.000 & 0 & 1 & 0.000 \\
\hline Spot & 0 & 481 & 0.000 & 0 & 1,502 & 0.000 \\
\hline Stud & 0 & 687 & 0.000 & 0 & 38 & 0.000 \\
\hline
\end{tabular}

\section{Discussion}

\subsection{Reclassification of Non-alternating Locative Verbs}

In this section, the verbs with significant values in FPR are organized. The table shows a verb's frequency, standard error, and confidence interval along with the FPR in both COCA and GloWbE. It indicates which verbs change their classes and how semantic and syntactic changes have taken place in the language. 
There is no significant value in type 1 . That is, language use of Figure-only verbs has not been changed over time. On the other hand, a few Ground-only verbs in type 2, which are supposed to show 0 in their FPRs, don't work as they were intended. 10 verbs don't have 0 in FPR and one verb has 0 in Frequency as shown in the following Table 6.

Table 6. Significant FPRs in type 2

\begin{tabular}{|c|c|c|c|c|c|c|c|c|}
\hline \multirow[b]{2}{*}{ Verbs } & \multicolumn{4}{|c|}{ COCA } & \multicolumn{4}{|c|}{ GloWbE } \\
\hline & $\begin{array}{c}\text { Fre- } \\
\text { quency }\end{array}$ & FPR & SE & $\begin{array}{c}\text { Confidence } \\
\text { interval }\end{array}$ & $\begin{array}{c}\text { Fre- } \\
\text { quency }\end{array}$ & FPR & SE & $\begin{array}{c}\text { Confidence } \\
\text { Interval }\end{array}$ \\
\hline Flood & 1723 & 0.182 & 0.0092 & $0.1638 \sim 0.2002$ & 6043 & 0.131 & 0.0043 & $0.1225 \sim 0.1395$ \\
\hline Face & - & - & - & & - & - & - & \\
\hline Inlay & 7 & 0.571 & 0.1870 & $0.2044 \sim 0.9376$ & 36 & 0.778 & 0.0693 & $0.6422 \sim 0.9138$ \\
\hline Fill & 29306 & 0.0064 & 0.0005 & $0.0055 \sim 0.0073$ & 83104 & 0.006 & 0.0003 & $0.0055 \sim 0.0065$ \\
\hline Imbue & 945 & 0.049 & 0.0070 & $0.0352 \sim 0.0628$ & 3016 & 0.084 & 0.0050 & $0.0741 \sim 0.0939$ \\
\hline Replenish & 136 & 0.390 & 0.0418 & $0.3080 \sim 0.4720$ & 584 & 0.409 & 0.0203 & $0.3691 \sim 0.4489$ \\
\hline Intersperse & 615 & 0.026 & 0.0064 & $0.0134 \sim 0.0386$ & 2292 & 0.003 & 0.0011 & $0.0008 \sim 0.0052$ \\
\hline Interweave & 291 & 0.333 & 0.0276 & $0.2788 \sim 0.3871$ & 1048 & 0.261 & 0.0136 & $0.2344 \sim 0.2876$ \\
\hline Ripple & 138 & 0.159 & 0.0311 & $0.0980 \sim 0.2200$ & 104 & 0.438 & 0.0954 & $0.3426 \sim 0.5334$ \\
\hline Soak & 738 & 0.389 & 0.0179 & $0.3538 \sim 0.4242$ & 1327 & 0.358 & 0.0132 & $0.3322 \sim 0.3878$ \\
\hline Plug & 1764 & 0.891 & 0.0074 & $0.8765 \sim 0.9055$ & 6117 & 0.959 & 0.0025 & $0.9540 \sim 0.9640$ \\
\hline
\end{tabular}

A frequency of 0 means that the verb is no longer used with the meaning of locativization. This verb face should be ruled out of the locative verbs. Among the 11 verbs here, 10 verbs should change their class from a Ground-only verb to an alternating verb, which have a shade background.

\subsection{A Revised Classification of Non-alternating Locative Verbs}

Based on the results of the previous sections, there is not any change in the class members in Type 1 . The 10 verbs in Type 2 change their class from the Ground-only verb class to the alternating verb class, and one verb face is excluded from the locative verbs, since it is no longer defined by its locativization. The original total number of 70 is reduced to 60 in the Ground-only verb class. 10 verbs 8 ) change their class 
from the Ground-only verb class to an alternating verb class. That is, the number of alternating verbs in both researchers' classifications has now grown by 10 respectively. ${ }^{9)}$

Table 7. A revised classification of Non-alternating locative verbs

\begin{tabular}{|c|c|}
\hline Types & Verbs \\
\hline $\begin{array}{l}\text { Figure only verbs } \\
\qquad(\mathrm{N}=15)\end{array}$ & $\begin{array}{l}\text { Dribble, drip, dump, ladle, pour, shake, slop, slosh, spill, coil, spin, } \\
\text { twirl, twist, whirl, wind }\end{array}$ \\
\hline $\begin{array}{l}\text { Ground only verbs } \\
\qquad(\mathrm{N}=60)\end{array}$ & $\begin{array}{l}\text { Cover, pave, bandage, deluge, douse, inundate, blanket, coat, } \\
\text { encrust, pad, plate, shroud, smother, tile, line, edge, pollute, adorn, } \\
\text { infect, season, endow, trim, clutter, deck, dirty, embellish, enrich, } \\
\text { festoon, garnish, litter, ornament, soil, stain, taint, drench, } \\
\text { interlace, interlard, interleave, intersperse, lard, vein, impregnate, } \\
\text { saturate, suffuse, block, lash, choke, clog, dam, stop up, bind, } \\
\text { entangle, bombard, blot, dapple, riddle, speckle, splotch, spot, stud }\end{array}$ \\
\hline
\end{tabular}

\subsection{Comparison of Reclassified Verbs with COHA}

It needs be verified how the reclassified verbs were used when the researcher's study was being conducted. They might have just misclassified those verbs in the classification. The Corpus of Historical American English (http://corpus.byu.edu/ coha/) (hereafter, COHA) is used for this purpose. COHA is the largest corpus of historical English and allows us to quickly and easily search more than 400 million words of text of American English from 1810 to 2009. As COHA provides findings as a unit over 10-year periods, it can be possible to collect certain periods of data. Thus, the data from 1810 to 2009 was only collected in this study because the period of 1990-2009 overlaps with COCA ${ }^{10)}$.

8) fill, flood, inlay, imbue, replenish, intersperse, interweave, ripple, soak, plug

9) 〈Alternating Locative verbs〉

Levin's classification (1993): brush, cram, crowd, cultivate, dab, daub, drape, drizzle, dust, hang, heap, inject, jam, load, mound, pack, pile, plant, plaster, ?prick, pump, rub, scatter, seed, settle, sew, shower, slather, smear, smudge, sow, spatter, splash, splatter, spray, spread, sprinkle, spritz, squirt, stack, stick, stock, strew, string, stuff, swab, ?vest, ?wash, warp $(\mathrm{N}=49)$

Pinker's classification (1989): brush, dab, daub, plaster, rub, slather, smear, smudge, spread, streak, heap, pile, stack, inject, spatter, splash, splatter, spray, sprinkle, squirt, scatter, sow, strew, pack, cram, stuff, crowd, jam, wad, load, stock $(\mathrm{N}=31)$

Alternating locative verbs will be investigated along with the verbs which change their class from Ground-only verbs to alternating verbs from both synchronic and diachronic perspectives.

10) NOTE: COHA 1819-2009 (In this study, 1819-1898)

COCA $1990-2012$

GloWbE 2012-2013 
Table 8. FPRs of 10 reclassified verbs in COHA

\begin{tabular}{ccccc}
\hline & F prep G & G prep F & FPR & SE \\
\hline \hline Flood & 56 (into 4, onto 3, on 41, over 8) & 1,270 (with 1,270) & 0.056 & 0.012 \\
Inlay & 0 & 7 (with 7) & 0.000 & 0.000 \\
Fill & 10 (into 10) & 31,157 (with 31,157) & 0.000 & 0.000 \\
Imbue & 2 (into 1, in 1) & 1,050 (with 1,050) & 0.000 & 0.000 \\
Replenish & 1 (into 1) & 113 (with 113) & 0.000 & 0.000 \\
Intersperse & 35 (into 28, in 7) & 753 (with 753) & 0.044 & 0.007 \\
Interweave & 27 (into 23, in 4) & 469 (with 469) & 0.054 & 0.010 \\
Ripple & 1 (into 1) & 72 (with 72) & 0.000 & 0.000 \\
Soak & 99 (into 99) & 292 (with 292) & 0.253 & 0.011 \\
Plug & 183 (into 183) & 91 (with 91) & 0.668 & 0.028 \\
\hline
\end{tabular}

According to the results of COHA, five verbs fall into alternating verb class: flood, intersperse, interweave, soak and plug in the dark background. Their values are significant, which means they had been used as an alternating verb before Levin and Pinker conducted research. Can we assume that this discrepancy comes from researcher's error that is possibly caused by method of classification such as subjective intuition?

The other five verbs are involved in Ground-only verbs in both COHA's result and previous researchers' classification. It reveals that some of the non-alternating locative verbs definitely changed in their use. That is, syntactic changes have taken place in the language over time.

\section{Summary and Concluding Remarks}

This research investigates English non-alternating locative verbs, and reclassifies them. Each of these verbs is observed with two corpora: COCA, GloWbE. Thanks to the design of each one, they are the most suitable corpora to investigate current and ongoing changes in the language. The two classifications which were previously researched by Pinker and Levin respectively are fundamentally used for choosing target verbs in the study. The data collected from the two corpora are studied from the perspective of an argument order between Figure and Ground and it reveals that 
10 verbs have changed in their syntactic use. All of the verbs are moved from the Ground-only verbs to the alternating verbs and they are reclassified. In addition, the reclassified verbs were investigated with historical language corpus, $\mathrm{COHA}$, because of the possibility that they might have been misclassified by researchers. According to the result of COHA, five verbs had been used as alternating verbs, which makes us assume that researchers may have made errors. However, five verbs are rightly classified and they are empirically proved. That is, they have definitely changed in their syntactic use and it has taken place over time.

This research has been done using an empirical method, corpus. Corpus is a sampling of words and generally considered not ideal for a precise reflection of the human language, which is a common criticism leveled against the corpus. To minimize statistical errors, two corpora are used in the study and also standard error, margin of error, and confidence intervals are calculated for every verb individually in the course of analysis and reclassification. It is worth finding a few examples which do not work as they were intended to be used, which can be evidence that locative verbs have been changing in terms of argument order in a sentence as time passes.

This study reveals that the language has changed in its syntactic use over time. Accordingly, the study presents a revised classification of non-alternating locative verbs. It needs to take a closer look at the direction of movement of the reclassified verbs here. All of the reclassified verbs originally belonged to Ground-only verbs and move to an alternating verb class. They used to be used as a Ground-only verb and considered the argument order as entrenched or preempted. It would be a natural question to ask what factors were involved in this change. Among the factors, what has a fundamental and great effect on this syntactic language change. Addressing this question would be the next research purpose and it would be interesting to ascertain research on other language changes.

\section{References}

Anderson, Stephen. (1971). On the role of deep structure in semantic interpretation. Foundations of Language 6, 197-219.

Anderson, Stephen. (1977). Comment on the paper by Wasow, In P. Culicover, I. Wasow, and A. Akmajian, eds., Formal Syntax. New York: Academic Press.

Carter, Ronald. (1988). On linking: Papers by Richard carter. In B. Levin and C. Tenny, eds.,

Lexicon Project Working Papers, 25. Cambridge, MA: MIT Center for Cognitive Science. Croft, William. (1991). Syntactic Categories and Grammatical Relations. Chicago: University of 
Chicago Press.

Croft, William. (2000). Explaining Language Change. An Evolutionary Approach. Harlow: Longman.

Davies, Mark. (2008). The Corpus of Contemporary American English: 450 million words, 1990-2012. Available online at http://corpus.byu.edu/coca/

Davies, M. (2010). The Corpus of Historical American English: 400 million words, 1810-2009. Available online at http://corpus.byu.edu/coha/

Davies, Mark. (2013). Corpus of Global Web-Based English: 1.9 billion words from speakers in 20 countries Available online at http://corpus.byu.edu/glowbe/

Dixon, Ronald. (1989). Subject and Object in Universal Grammar. Oxford: Oxford University Press.

Dixon, Roland. (1991). A New Approach to English Grammar, On Semantic Principles. Oxford: Oxford University Press.

Gawron, Mark. (1983). Lexical Representations and the Semantics of Complementation. Doctoral dissertation, University of California.

Gruber, Jeffrey. (1976). Lexical Structures in Syntax and Semantics. Amsterdam: North- Holland. Hall, Brian. (1965). Subject and Object in English. Doctoral dissertation, Massachusetts Institute of Technology.

Jolly, Jean. (1987). An analysis of selected english prepositions within the framework of role and reference grammar. Davis Working Papers in Linguistics 2, 60-114. Davis, CA: University of California.

Jackendoff, Ray. (1985). The Argument Structure of Put. Unpublished manuscript. Waltham: Brandeis University.

Jeffries, Lesley and Penny Willis. (1984). A return to the spray paint issue. Journal of Pragmatics 8, 715-729.

Larson, Richard. (1990). Double objects revisited: Reply to jackendoff. Linguistic Inquiry 21, 589-632.

Levin, Beth. (1993). English Verb Classes and Alternations: A Preliminary Investigation. Chicago: University of Chicago Press.

Levin, Beth and Hovav Rappaport.(1988). Non-event -er Nominals: A Probe into Argument Structure. Linguistics 26, 1067-1083.

Pinker, Steven. (1989). Learnability and Cognition: The Acquisition of Argument Structure. Cambridge, MA: MIT Press.

Rappaport, Hovav and Beth Levin.(1985). A Case Study in Lexical Analysis: The Locative Alternation. Unpublished manuscript. MIT Center for Cognitive Science.

Rappaport, Hovav and Beth Levin. (1992). -er Nominals: Implications for a theory of argument structure. In T. Stowell and E. Wehrli. eds., Syntax and Semantics 24: Syntax and the Lexicon. New York: Academic Press. 
Wookyung Park

Department of English Language and Literature

Kyungpook National University

80 Daehakro, Bukgu, Daegu, Korea

E-mail: gisg@hanmail.net

Received: October 31, 2017

Revised version received: April 5, 2018

Accepted: April 6, 2018 